\title{
Partisipasi petani ubi kayu (Manihot esculenta) dalam upaya konservasi lahan kering di Kota Pekanbaru
}

\author{
Nazri Zulfadjrin ${ }^{1}$, Sukendi ${ }^{2}$, Nofrizal ${ }^{3}$ \\ ${ }^{1,2 .}{ }^{3}$ Program Studi Ilmu Lingkungan Program Pascasarjana Universitas Riau
}

Diterima: 12 April 2021| Disetujui: 29 April 2021 | Diterbitkan: 30 April 2021

\begin{abstract}
This research was conducted in September 2020 in Tenayan Raya District, Pekanbaru City. This study describes the participation of cassava farmers in the conservation of dry land according to the Land Conservation Index (IKK) and analyzes socio-economic factors that influence these conservation activities. Respondents in this study were cassava farmers who have farming land over one hectare. Conservation activities carried out by farmers to carry out dry land conservation include, making terraces or uplands and planting in the direction of contour lines or crossing slopes, use of mulch or terrace reinforcing grass, use of manure and construction of drainage channels. The approach used in this study used survey methods and interviews with cassava farmers to obtain farmer socio-economic data, and analyzed using simple regression methods. The results showed that the farmers carried out dry land conservation activities at a moderate level. The influence of socio-economic factors that affect the dry land conservation activities of cassava farmers is the factor of acceptance and land ownership status.
\end{abstract}

Keywords: Cassava farmers; dry land; soil conservation; participation

Kota Pekanbaru merupakan Ibukota Provinsi Riau yang memiliki dua belas Kecamatan dengan total luasan wilayah 63.226 ha (Dinas Pertanian, 2018). Penggunaa lahan di Kota Pekanbaru 55\% dari luasan wilayah adalah sektor pertanian dan perkebunan sedangkan $45 \%$ lainnya adalah lahan bukan pertanian sepeti jalan, pemukiman, dan sektor usaha lainnya (Dinas Pertanian Kota Pekanbaru, 2018). Usaha dalam sektor pertanian merupakan salah satu pekerjaan masyarakat Kota Pekanbaru. Potensi pertanian di Kota Pekanbaru sangatlah besar dilihat dari luas lahan yang tersedia untuk berbagai komoditi pertanian seperti palawija dan hortikultura. Saat ini Di Kota Pekanbaru sedang dikembangkannya sentral ubi kayu di Kecamatan Tenayan Raya. Pemilihan ubi kayu sebagai komoditi yang dikembangkan di daerah tersebut sangat mempunyai peluang yang besar dilihat dari besarnya permintaan pasar untuk salah satu tanaman pangan tersebut. Ubi kayu dapat diolah menjadi aneka pengolahan makanan seperti keripik, tepung tapioka, tapai, dan sebagai bahan baku industri seperti lem dan bioethanol. Pada Tahun 2018, produksi ubi kayu di Kota Pekanbaru mencapai 5.461 ton dengan luas tanam 122 ha yang terdapat di empat Kecamatan di Kota Pekanbaru yaitu Kecamatan Tenayan Raya, Marpoyan Damai, Rumbai, dan Rumbai Pesisir merupakan lahan kering yang mempunyai kemiringan lahan 0- 40\% (Dinas Pertanian Kota Pekanbaru, 2018).

Potensi lahan kering sebagai salah satu penyumbang bahan pangan sudah diketahui, namun belum secara baik dipahami fungsi lahan kering yang sering ditelantarkan dalam konteks teknisnya sebagai lahan potensial penghasil bahan pangan. Potensi lahan kering sebagai penyumbang pangan didunia masih luas. Sekitar $40 \%$ lahan pertanian dunia adalah lahan kering dan distribusi lahan kering ini terbesar berada di Asia sebesar 34,4\% di Afrika sebesar 24,15\%, di Amerika sebesar 24,03 \% yang dapat menyediakan produksi cerelia dan peternakan, habitat bagi spesies tanaman dan hewan serta mikroba. Berdasarkan agroekosistem, daratan di Indonesia yang tergolong daratan kering atau lahan kering yang memiliki luasan yang sangat luas yaitu 147,8 juta ha.

Kenyataan yang banyak ditemukan di lahan kering yang merupakan daerah perbukitan, sebagian besar petani di daerah tersebut tidak menerapkan tindakan konservasi tanah yang memadai. Sistem pertanaman yang banyak dilakukan pada bedengan atau gulu dan searah lereng. Sistem pertanaman tersebut bertujuan agar kondisi aerasi disekitar akar tanaman menjadi baik sehingga pertumbuhan akar menjadi baik dan hasilnya menjadi tinggi. Pengaruh sistem pertanaman tersebut akan berakibat lebih buruk, yaitu dapat menyebabkan aliran permukaan lahan terkonsentrasi menjadi semakin banyak dan kecepatannya akan meningkat.

Berdasarkan keadaan yang ada, maka salah satu alternatif untuk mengantisipasi masalah tersebut adalah dengan upaya-upaya pengelolaan yang tepat untuk meningkatkan kualitas tanah sehingga kerusakan tanah dapat dicegah, upaya-upaya tersebut antara lain melakukan pemeliharaan lahan yang tepat serta dapat diterapkan oleh petani seperti pengolahan tanah yang baik serta memberikan pupuk 
organik untuk meningkatkan stabilitas struktur tanah dan agregat tanah sehingga dapat meningkatkan produktivitas lahan yang dicirikan dengan penurunan tingkat erosi dan limpasan permukaan serta peningkatan hasil panen. Berdasarkan uraian masalah diatas penulis ingin mengkaji tentang partisipasi petani dalam pengembangan ubi kayu dengan melakukan penerapan konservasi tanah di lahan kering oleh petani ubi kayu.

\section{METODE PENELITIAN}

Penelitian ini dilaksanakan di beberapa Kecamatan yang ada usahatani ubi kayu di Kota Pekanbaru dilahan kering dengan kemiringan yang bervariasi mulai dari $0 \%$ sampai kemiringan $40 \%$ untuk melihat besar partisipasi petani dlam penerapan pemeliharaan tanah dilahan kering yang dapat menyebabkan erosi. Penelitian ini akan dilaksanakan di bulan Oktober 2020 karena pada bulan tersebut memasuki awal musim hujan waktu yang tepat ketika persiapan lahan untuk penanaman ubi kayu . Penetapan lokasi penelitian dilakukan secara sengaja (purposive) dengan pertimbangan banyaknya lahan ubi kayu di Kecamatan Tenayan Raya. Untuk mendapatkan nilai IKK pada Setiap aktifitas mempunyai dua pilihan jawaban: untuk setiap aktivitas yang dilakukan petani diberi skor 1 dan jika tidak dilakukan diberi skor 0 , IKK dihitung dengan rumus:

$$
I K K=\frac{\text { Skor yang diperoleh }}{\text { Skor maksimum }} \times 100 \%
$$

Penilaian partisipasi para petani dalam konservasi lahan tersebut merujuk pada Suwarto (2012) diberikan dalam persentase (1 persen sampai dengan 100 persen). Besarnya penilaian yang diperoleh dari jawaban petani merupakan tingkat IKK yang mencerminkan upaya atau partisipasi para petani dalam konservasi lahan. Penggolongan IKK selanjutnya dibagi dalam empat kategori sebagai berikut: IKK sangat rendah, nilai partisipasi petani dalam konservasi lahan 1,00 persen sampai dengan 25,00 persen, IKK rendah, nilai partisipasi petani dalam konservasi lahan 26,00 persen sampai dengan 50,00 persen, IKK sedang, nilai partisipasi petani dalam konservasi lahan 51,00 persen sampai 75,00 persen, IKK tinggi, nilai partisipasi petani dalam konservasi lahan 76,00 persen sampai dengan 100,00 persen.

Faktor-faktor yang mempengaruhi partisipasi petani lahan kering dalam konservasi lahan dengan analisis regresi linier berganda dengan peubah tetap Indeks Kegiatan Konservasi (IKK) dan peubah tidak tetap: pendapatan keluarga petani, jumlah anggota keluarga, luas lahan, pendidikan petani dan status penguasaan lahan. Adapun model persamaannya:

$$
\mathrm{IKK}=\mathrm{a}+\mathrm{b}_{1} \mathrm{X}_{1}+\mathrm{b}_{2} \mathrm{X}_{2}+\mathrm{b}_{3} \mathrm{X}_{3}+\mathrm{b}_{4} \mathrm{X}_{4}+\mathrm{b}_{2} \mathrm{DS}+\mathrm{U}
$$

$\begin{aligned} \text { Keterangan: } & \\ \text { IKK } & =\text { Indeks Kegiatan Konservasi (\%) } \\ \mathrm{a} & =\text { Konstanta } \\ \mathrm{b} & =\text { Koefisien regresi } \\ \mathrm{X} 1 & =\text { Pendapatan keluarga petani (Rp) } \\ \mathrm{X} 2 & =\text { Jumlah anggota keluarga } \\ \mathrm{X} 3 & =\text { Luas lahan (ha) } \\ \mathrm{X} 4 & =\text { Pendidikan petani (tahun) } \\ \mathrm{DS} & =\text { Dummy (Status penguasaan lahan) } \\ \mathrm{U} & =\text { Kesalahan Pengganggu }\end{aligned}$

\section{HASIL DAN PEMBAHASAN}

Kota Pekanbaru adalah ibukota Provinsi Riau yang secara geografis terletak antara $101^{\circ} 14^{\prime}-101^{\circ} 34^{\prime}$ Bujur Timur dan $0^{\circ} 25^{\prime}$ - $0^{\circ} 45^{\prime}$ Lintang Utara, dengan ketinggian dari permukaan laut berkisar 5 - 50 mdpl. Permukaan wilayah bagian utara landai dan bergelombang dengan ketinggian berkisar antara 5-11 meter. Kota Pekanbaru dibelah oleh Sungai Siak yang mengalir dari barat ke timur. memiliki beberapa anak sungai antara lain Sungai Umban Sari, Air Hitam, Siban, Setukul, Pengambang, Ukul, Sago, Senapelan, Limau, Tampan dan Sungai Sail. Kota Pekanbaru pada umumnya beriklim tropis dengan suhu udara maksimum berkisar antara $34,1^{\circ} \mathrm{C}-35,6^{\circ} \mathrm{C}$ dan suhu minimum antara $20,2^{\circ} \mathrm{C}-23,0^{\circ} \mathrm{C}$. Curah hujan antara 38,6 - 435,0 $\mathrm{mm} /$ tahun dengan keadaan musim berkisar musim hujan jatuh pada bulan Januari sampai dengan April dan September sampai dengan Desember. Musim kemarau jatuh pada bulan Mei sampai dengan Agustus (Badan Statistik Kota Pekanbaru, 2019). 
ZONA

Jurnal Lingkungan

ISSN : 2502-6496 (Print) | 2502-6496 (Online)

Volume 5, No 1, April 2021, p. 29-35

http://zona.pelantarpress.co.id

Kawasan pusat kota dan sekitarnya relatif datar dengan ketinggian rata-rata antara $10-20$ meter di atas permukaan laut. Sedangkan kawasan Tenayan Raya dan sekitarnya umumnya mempunyai ketinggian antara 25 - 50 meter di atas, permukaan laut. Kawasan yang relatif tinggi dan berbukit terutama dibagian utara kota, khususnya di Kecamatan Rumbai dan Rumbai Pesisir dengan ketinggian rata-rata sekitar 50 meter di atas permukaan laut (Badan Statistik Kota Pekanbaru, 2019).

Kecamatan Tenayan Raya merupakan salah satu kecamatan di wilayah Kota Pekanbaru, terdiri atas 129 RW dan 462 RT. Luas wilayah Tenayan Raya adalah 171,27 km². Batas-batas wilayah Kecamatan Tenayan Raya adalah sebelah timur berbatasan dengan Kabupaten Pelalawan dan Kabupaten Siak, batas sebelah barat berbatasan dengan sungai sail, sebelah utara berbatasan dengan sungai siak, sebelah utara berbatasan dengan Kabupaten Kampar. Kecamatan Tenayan Raya mempunyai 13 kelurahan terdiri dari Kelurahan Kulim, Tengkereng Timur, Rejosari, Bencah Lesung, Sialang Rampai, Pebatuan, Mentangor, Pematang Kapau, Sialang Sakti, Tuah Negeri, Melebung, Industri Tenayan, dan Bambu Kuning (Badan Statistik Kota Pekanbaru, 2019). Kecamatan Tenayan Raya merupakan salah satu sentra ubi kayu terbesar di Kota Pekanbaru. Potensi produksi ubi kayu di Kecamatan Tenayan Raya yaitu 17.499,3 ton.

\section{Karakteristik Petani Responden}

Karakteristik petani yang dibahas yaitu meliputi, luas lahan, jumlah tenaga kerja, pendidikan, penerimaan dan status penguasaan lahan. Semua responden adalah petani yang menanam ubi kayu dengan luas penguasaan lahan di atas satu hektar. Responden petani ubi kayu yang didapatkan berjumlah dua puluh orang. Dari hasil wawancara didapatkan karakteristik petani ubi kayu di Kecamatan Tenayan Raya.

\section{Responden Berdasarkan Luas}

Luas lahan yang dikuasai petani pada saat dilakukannya penelitian yang dinyatakan dalam hektar. Dari 20 responden petani, petani yang penguasaan lahan diatas 2 hektar sebesar 60 persen dari 20 responden sebanyak 12 orang. Menurut hasil penelitian Suwarto (2012) menyatakan luas penguasaan lahan juga meningkatkan partisipasi petani dalam konservasi lahan. Para petani kecil mempunyai kebutuhan utama bahan pangan, walaupun lahan usahataninya berkemiringan tinggi, pada umumnya masih menggunakan lahan tersebut untuk tanaman pangan. Jika petani berlahan luas, maka para petani dapat membudidayakan lahan tanaman sesuai kelas kemampuan lahan.

Jumlah tenaga kerja adalah banyaknya tenaga kerja yang dipakai oleh petani dalam usahatani ubi kayu tenaga kerja yang dipakai oleh petani adalah anggota keluarga. Jumlah tenaga kerja yang kurang dari empat orang dalam usahatani ubi kayu sebesar 50 persen sebanyak 10 orang responden dari 20 responden. Untuk penggunaan tenaga kerja 4-5 orang yang dipakai oleh petani sebesar 45 persen dengan 9 orang responden. Untuk penggunaan tenaga kerja diatas 5 orang didapatkan 6 orang responden dengan persentase 30 persen. Dari hasil wawancara rata-rata tenaga kerja yang dipakai oleh petani dalam satu hektar berjumlah dua orang.. Rincian pekerjaan yang dilakukan pekerja antara lain pengolahan tanah setelah panen, pembuatan guludan, dan penanaman dilakukan dalam rentang waktu tujuh hari sampai dengan dua minggu per-hektar. Pemakaian tenaga kerja dalam usahatani ubi kayu hanya dipakai untuk pengolahan tanah, penanaman, dan pemupukan. Sedangkan untuk perawatan tidak diperlukan tenaga kerja yang banyak biasanya petani merawat dengan tenaga sendiri sehingga menghemat biaya operasional. Pada saat pemanenan tidak diperlukan tenaga kerja dari petani sendiri, biasanya para pembeli atau pengempul yang menyediakan tenaga kerja untuk pemanen.

Pendidikan merupakan jenjang pendidikan formal yang diperoleh dari bangku sekolah yang telah diselesaikan oleh responden. Tingkat pendidikan paling banyak adalah SMA yaitu 17 orang atau sebesar 85 persen dari total responden. Sedangkan lainnya tamatan SMP yaitu 2 orang dengan persentase 10 persen dan tamatan D3 sebanyak 1 orang dengan persentase 5 persen dari total responden. Dari hasil yang didapatkan bahwa rata-rata pendidikan petani di Kecamatan Tenaya Raya berpendidikan SMA. Berdasarkan hasil estimasi, dapat dikemukakan bahwa tingkat pendidikan yang ditamatkan oleh tenaga kerja sektor pertanian di Sumatera mempunyai pengaruh positif dan signifikan terhadap produktivitas tenaga kerja sektor pertanian. Sa'adah (2015) terdapat hubungan positif dan signifikan antara tingkat pendidikan terhadap kegiatan konservasi. 
ZONA

Jurnal Lingkungan

ISSN : 2502-6496 (Print) | 2502-6496 (Online)

Volume 5, No 1, April 2021, p. 29-35

http://zona.pelantarpress.co.id

Penerimaan merupakan hasil pendapatan responden dari produksi ubi kayu dalam rupiah perhektar dalam sekali panen (9 bulan) dan dikonversi menjadi penerimaan dalam satu bulan di Kecamatan Tenayan Raya. Jumlah petani dengan pendapatan dibawah Rp 4.000.000 dan diatas Rp 4.000.000 sama. Rata-rata pendapatan petani ubi kayu di Kecamatan Tenayan Raya Rp 4.000.000/ bulan/ hektar . dilihat dari hasil yang didapatkan, petani ubi kayu di Kecamatan Tenayan Raya cukup besar. Dari pendapatan petani maka petani mendapatkan modal untuk produksi ushatani selanjutnya. Modal usahatani dibutuhkan untuk pengolahan lahan, dan perawatan tanaman ubi kayu. Dengan modal yang cukup petani seharusnya dapat melakukan pengolahan tanah sesuai dengan kegiatan konservasi lahan.

\section{Status Penguasaan Lahan}

Status penguasaan lahan dibagi menjadi dua kategori yaitu responden sebagai pemilik penggarap dan responden sebagai penyewa penggarap. Responden petani sebagai pemilik lahan penggarap sebanyak 9 responden dengan persentase 45 persen dan petani penyewa penggarap sebanyak 11 responden dengan persentase 55 persen. Dari hasil wawancara kepada responden petani penyewa penggarap dengan keterbatasan lahan untuk berusahatani, responden menyewa lahan dengan harga sewa Rp 4.000.000 / ha.

Petani di Kecamatan Tenayan Raya menanam ubi kayu dengan varietas ubi klenteng. Varietas tersebut digunakan untuk bahan baku keripik dan tapai ubi. Rata-rata petani berusia 27 sampai 55 tahun dengan latar belakang pendidikan lulusan SMA. Menurut hasil penelitian Suwarto (2012), umur tidak mempengaruhi penerapan konservasi lahan,. Umur dapat berkenaan dengan pengalaman kerja sebagai petani. Semakin lama berprofesi sebagai petani dalam pengolahan lahan dan pembudidayaan tanaman tersebut semakin maka semakin banyak pengalaman dan ilmu yang di peroleh turun-temurun.

\section{Partisipasi Petani dalam Konservasi Lahan}

Hasil pengukuran partisipasi para petani dalam konservasi lahan yang menggunakan 5 parameter, rata-rata partisipasi petani dalam konservasi lahan berada pada kategori sedang yaitu 51,99 persen. Kegiatan konservasi lahan dengan pembuatan teras atau guludan pada lahan yang miring (Y1) telah dilaksanakan dengan baik oleh para petani ubi kayu di Kecamatan Tenaya Raya. Sebanyak 85,5 persen dari 20 responden petani yang menerapkan pembuatan teras atau guludan. Menurut hasil penelitian Subekti, (2004) guludan dapat mengendalikan laju erosi sampai 92,3 persen untuk jarak guludan 22,0 m (1 buah) dan dapat mengendalikan erosi sampai dengan 98,9 persen pada jarak antar guludan $4,40 \mathrm{~m}$ (5 buah guludan). Selain itu Kumolontang, et al (2012) juga meneliti terjadi penurunan aliran permukaan dikarenakan guludan yang lebih banyak sehingga kesempatan air untuk infiltrasi lebih besar dan aliran permukaan berkurang. Kegiatan konservasi lahan dengan penerapan pengolahan lahan atau penanaman searah garis kontur (Y2) telah dilaksanakan dengan sangat baik . rata- rata para petani sudah menerapkan kegiatan penanaman searah garis kontur atau menyilang lereng. Kegiatan ini dipadukan dengan kegiatan pembuatan guludan sehingga akan lebih memperkecil terjadinya erosi. Keuntungan utama dari pengolahan tanah dan penanaman searah garis kontur yaitu terbentuknya penghambat aliran air sehingga dapat mengurangi kemungkinan terjadinya erosi.

Menurut hasil yang didapat partisipasi petani terhadap kegiatan penanaman rumput penguat teras atau penggunaan mulsa sangat rendah. Padahal menurut hasil penelitian Djajadi dalam Nanik, et al (2017) menyatakan bahwa pemberian mulsa dapat mengurangi penguapan serta terhindar dari pukulan langsung butir-butir air hujan, mulsa juga memiliki fungsi lain yaitu memperkuat agregat dan porositas tanah, mengurangi kecepatan dan daya kikis aliran permukaan. Selain dari manfaat terhadap konservasi tanah mulsa mempunyai keuntungan dari pemeliharaan lahan seperti menekan pertumbuhan gulma yang merugikan untuk tanaman utama, menurut Radics dan Boghar dalam Nanik, et al (2017) mulsa batang jagung dapat menurunkan kerapatan gulam dan bobot kering gulma. Rendahnya bobot kering gulma diakibatkan oleh ruang tumbuh gulma dan cahaya matahari yang terbatas akibat tertutupi mulsa batang jagung sehingga biji-biji gulma terhalangi dan perkecambahan biji gulma terhambat. Hal ini sangat menguntungkan petani ubi kayu apabila melaksankan kegiatan konservasi ini, tidak hanya mendapat keuntungan untuk pelestarian tanah tetapi dapat menekan biaya perawatan untuk pembersihan gulma.

Partisipasi petani terhadap kegiatan konservasi menggunakan pupuk kandang atau pupuk organik menurut hasil yang didapat sangat rendah. Rendahnya partisipasi petani terhadap penggunaan pupuk kandang atau pupuk organik disebabkan oleh harga dan kebutuhan pupuk yang belum memadai dan terjangkau . Pupuk kandang atau pupuk organik dapat diperoleh apabila petani ubi kayu juga mempunyai 
hewan ternak. Dengan adanya hewan ternak dapat menyuplai pupuk ke lahan dan tersedianya pakan hijauan dari lahan untuk usaha ternak petani ubi kayu. Pentingnya penggunaan bahan organik dalam mengatasi lahan kritis di Kabupaten Gunung Kidul yang dilakukan selama 4,5 tahun dengan pemberian 510 ton ha $\mathrm{a}^{-1}$ pupuk organic yang dikombinasikan dengan perlakuan lainnya berhasil menanggulangi lahan kritis. Partisipasi petani terhadap pembuatan saluran drainase (Y5) telah terlaksana dengan baik. Sebenarnya para petani sudah lama mengetahui fungsi pembuatan saluran drainase untuk lahan mereka. Pembuatan saluran drainase searah lereng merupakan salah satu usah petani untuk membuang air yang berlebih dari permukaan tanah yang dapat merugikan tanaman sehingga tanah tersebut dapat difungsikan secara optimal. Sesuai hasil penelitian, maka tingkat partisipasi petani dalam konservasi lahan pada parameter yang telah mencapai kategori sedang sebesar 55\%, perlu adanya kesadaran dan pemahaman tentang kegiatan konservasi tanah yang belum terlaksana dengan baik untuk meningkatkan partisipasi petani yang lebih baik dalam pelaksanaan kegiatan konservasi.

\section{Faktor-Faktor Berpengaruh Terhadap IKK}

Dari hasil analisis data yang diperoleh nilai IKK dari petani ubi kayu di Kecamatan Tenayan Raya berkategori sedang dengan nilai IKK 52 persen. Rendahnya nilai IKK disebabkan oleh beragamnya petani menerapan kegiatan konservasi lahan. Model regresi yang disusun dapat dipergunakan, dalam hal ini F-tabel nyata pada taraf kesalahan 1 persen.

Tabel 1. Hasil Analisis faktor-faktor yang mempengaruhi kegiatan konservasi lahan di Kecamatan

\begin{tabular}{llrrrl}
\multicolumn{7}{c}{ Tenayan Raya } \\
\hline & Koef. Reg & T.hit. & T. Tabel & Sig \\
\hline Luas (X1) & 1.085 & 1.879 & 2.2622 & 0.081 & $\begin{array}{l}\text { Tidak } \\
\text { Berpengaruh } \\
\text { Tidak } \\
\text { Berpengaruh }\end{array}$ \\
$\begin{array}{l}\text { Jumlah anggota rumah } \\
\text { tangga yang bekerja }\end{array}$ & 0.223 & 0,700 & 2.2622 & 0.495 \\
$\begin{array}{l}\text { (X2) } \\
\text { Pendidikan (X3) }\end{array}$ & 0.324 & 1.703 & 2.2622 & 0.111 & $\begin{array}{l}\text { Tidak } \\
\text { Berpengaruh }\end{array}$ \\
Penerimaan (X4) & -1.468 & -2.703 & 2.2622 & 0.017 & $\begin{array}{l}\text { Berpengaruh } \\
\text { Negatif }\end{array}$ \\
Status Lahan (X5) & 0.579 & 2.766 & 2.2622 & 0.015 & $\begin{array}{l}\text { Berpengaruh } \\
\text { Positif }\end{array}$ \\
$\quad$ Konstanta & 22.729 & 1.286 & & 0.219 & \\
Adjusted $R$ Square & 0.393 & & & & \\
$\quad$ F-hitung & & 3.456 & & &
\end{tabular}

Sumber: Analisis Data Primer, 2020

Hasil analisis regresi tersebut dapat dirumuskan kedalam bentuk persamaan regresi berganda, sebagai berikut

$$
\mathrm{Y}=22.729+1,085 \mathrm{X} 1+0,223 \mathrm{X} 2+0,324 \mathrm{X} 3+(-1,468) \mathrm{X} 4+0,579 \mathrm{X} 5
$$

Dari formulasi model diatas menunjukkan bahwa:

1. Nilai konstanta sebesar 22.729 yang berarti bahwa jika variabel independen dianggap konstan maka variabel dependen Indeks Kegiatan Konservasi (IKK) mempunyai nilai konstan sebesar 22.729 .

2. Nilai koefisien untuk variabel independen luas lahan (X1) bernilai positif yaitu sebesar 1,085 yang berarti apabila luas lahan yang dipakai mengalami peningkatan $1 \%$ maka Indeks Kegiatan Konservasi (IKK) meningkat sebesar 1,085\%.

3. Nilai koefisien untuk variabel independen tenaga kerja (X2) bernilai positif yaitu sebesar 0,223 yang berarti apabila tenaga kerja yang dipakai menggalami peningkatan $1 \%$ maka Indeks Kegiatan Konservasi (IKK) lahan meningkat sebesar 0,22\%.

4. Nilai koefisien untuk variabel independen pendidikan (X3) bernilai positif yaitu sebesar 0,324 yang berarti apabila lamanya pendidikan petani mengalami peningkatan $1 \%$ maka Indeks Konservasi Lahan (IKK) meningkat sebesar $0,32 \%$ 


\section{ZONA}

5. Nilai koefisien untuk variabel independen penerimaan (X4) bernilai negatif yaitu sebesar -1.468 yang berarti apabila penerimaan meningkat maka $1 \%$ maka Indeks Konservasi Lahan (IKK) terjadi penurunan $1,46 \%$

6. Nilai koefisien untuk variabel independen status penguasaan lahan (X5) bernilai positif yaitu sebesar 1.085 yang berarti apabila penerimaan meningkat maka 1\% maka Indeks Konservasi Lahan (IKK) terjadi $1,08 \%$

Analisis regresi pada Tabel 1. menunjukkan nilai adjusted $R$ square sebesar 0.393 yang dapat diartikan bahwa 39.3 persen variasi variabel dependen yang mempengaruhi indeks kegiatan konservasi variabel independen. Selanjutnya juga diperoleh bahwa nilai F-hitung (3.456) lebih besar dari F-tabel (2.81) pada tingkat kesalahan 5 persen. Dengan demikian hipotesis yang menyatakan IKK dipengaruhi oleh luas lahan, tenaga kerja, pendidikan, penerimaan, dan status penguasaan lahan dapat diterima atau terbukti sebesar 39.3 persen.

Dari hasil pengolahan data dapat dilihat pengaruh variabel dependen secara parsial terhadap faktor dependen dengan melihat hasil dari t-hitung dibandingkan dengan t-tabel. Dari hasil analisis data yang diolah maka didapatkan nilai t-tabel 2,262 dengan taraf signifikansi $0,025 \%$. Sebagaimana hasil analisis, nilai t-hitung faktor luas lahan ( X1) adalah 1.879 lebih kecil dari nilai t-tabel yang didapat yaitu 2,262 yang menyatakan bahwa tidak ada pengaruh luas lahan secara parsial terhadap Indeks Kegiatan Konservasi. Hasil analisis pengaruh faktor tenaga kerja (X2) terhadap Indeks Kegiatan Konservasi dengan nilai t-hitung 0,700 lebih kecil dibandingankan t-tabel 2,262 menyatakan ada pengaruh secara parsial jumlah tenaga kerja terhadap Indeks Kegiatan Konservasi. Semakin banyak tenaga kerja maka kegiatan konservai dapat dilaksanakan dengan baik. Banyaknya jumlah pekerja pada suatu lahan menyebabkan banyaknya pengeluaran untuk upah pekerja sehingga menyebabkan besarnya biaya operasional yang dikeluarkan untuk tanaman ubi kayu. Sebaliknya jika pekerja lahan tersebut adalah kelurga petani tersebut dapat menekan biaya upah pekerja sehingga dapat melaksanakan kegiatan konservasi sesuai dengan IKK.

Untuk faktor lamanya pendidikan petani didapatkan nilai t-hitung (1.703) lebih kecil dari t-tabel $(2,093)$ sehingga dapat disimpulkan bahwa tidak ada pengaruh faktor lamanya pendidikan terhadap kegiatan Konservasi (IKK). Lamanya pendidikan formal tidak menjamin petani dapat memahami kegiatan konservasi lahan. Pengetahuan tentang kegiatan konservasi lahan tidak didapatkan hanya dari pendidikan formal saja tetapi didapatkan dari pendidikan non-formal seperti pelatihan tentang konservasi lahan. Pengalaman dalam usahatani konservasi menggambarkan bahwa usahatani konservasi yang diharapkan akan dikembangkan petani dalam mengusahakan lahan kering yang mereka miliki, ternyata tidak mudah untuk diadopsi dan dijalankan petani. Walaupun tujuannya adalah untuk meningkatkan kesejahteraan petani dan sekaligus menjaga kelestarian lahan, akan tetapi kenyataannya petani cenderung tidak berdaya untuk menjalankannya.. Berbagai permasalahan yang dihadapi petani membuat mereka sulit untuk mengembangkan usaha pada lahan kering yang mereka miliki.

Hasil analisis penerimaan petani didapatkan nilai t-hitung (-2.0703) lebih besar dari t-tabel (2.093). Dari hasil uji yang didapat bahwa penerimaan berpengaruh negatif terhadap Indeks Konservasi Lahan. Semakin besar penerimaan petani yang didapat maka modal akan bertambah. Dengan modal yang cukup petani semakin bersemangat untuk melakukan kegiatan konservasi karena tidak sedikit biaya yang dikeluarkan untuk pelaksaan kegiatan konservasi seperti pemberian mulsa, pembuatan teras guludan dan pemberian pupuk kandang. Secara teoritik realita yang dihadapi petani konservasi dengan apa yang diungkapkan Sinukaban dalam Edwar (2005) bahwa perwujudan usahatani konservasi itu tidaklah mudah karena ciri petani dan pertanian di daerah miskin kurang kondusif bagi perwujudan usahatani konservasi. Begitu juga Barbier dalam Edwar (2005) mengatakan bahwa penerapan teknologi konservasi ditentukan oelh tingkat keuntungan usahatani yang dijalankan. Petani yang berada dilapisan atas mungkin dapat menerapkan secara terus menerus karena tingginya tingkat produktivitas dan penerimaan yang diperoleh dari usahataninya. Sedangkan petani dengan penerimaan atauu pengasilan yang rendah mungkin sadar akan meanfaat teknologi konservasi tersebut, tetapi tidak mampu untuk menerapkannya.

Hasil analisis, nilai t-hitung penguasaan lahan $(2,766)$ lebih besar dari nilai t-tabel (2.093) menyatakan bahwa status penguasaan lahan (X5) berpengaruh terhadap indeks konservasi lahan. Dari hasil analisa regresi, penguasaan lahan mempengaruhi petani untuk melaksanakan kegiatan konservasi. Penguasaan lahan baik petani pemilik penggarap ataupun petani penyewa penggarap sudah intensif dalam pengolahan kegiatan konservasi lahan. Pada umumnya petani yang memiliki lahan dan menggarap lahan memiliki rasa kepedulian terhadap kualitas lahannya. Menurut Edwar (2005) Pada umumnya petani 
penyewa mengeluarkan biaya lebih untuk biaya penyewaan lahan, sehingga petani lebih mementingkan produksi secara optimal guna penghematan biaya operasional.

\section{KESIMPULAN}

Tingkat partisipasi petani ubi kayu sesuai Indeks Konservasi Lahan (IKK) terhadap rata-rata para petani responden berpartisipasi pada tingkat sedang dengan persentase secara keseluruhan $55 \%$ dalam konservasi lahan. Penanaman rumput penguat teras atau penggunaan mulsa dan penggunaan pupuk kandang tidak dilaksanakan oleh petani responden. Hal tersebut karena para petani kesulitan dalam penyediaan pupuk kandang dan mulsa serta membutuhkan biaya yang tidak sedikit. Pada kegiatan pembuatan guludan, penanaman searah garis kontur dan pembuatan drainase sudah dilaksanakan dengan baik dan perlu dipertahankan. Faktor- faktor sosial ekonomi yang mempengaruhi Indeks Konservasi Lahan (IKK) adalah luas lahan, jenjang pedidikan, jumlah tenaga kerja, penerimaan dan status penguasaan lahan sebesar 39,3 persen terhadap IKK. Secara parsial faktor luas lahan, jenjang pendidikan, dan status penguasaan lahan tidak ada pengaruh terhadap indeks konservasi lahan. Sedangkan faktor pendapatan dan jumlah tenaga kerja berpengaruh terhadap indeks konservasi lahan.

\section{DAFTAR PUSTAKA}

Badan Pusat Statstik Kota Pekanbaru. (2019). Pekanbaru dalam Angka, Pekanbaru

Dinas Pertanian Kota Pekanbaru, (2018). Statistik Pertanian Kota Pekanbaru. Kota Pekanbaru

Edwar. (2005) Pengalaman Petani dalam Konservasi Lahan Melalui Usaha Tani. Universitas Hasanuddin. Makasar.

Kumolontang, (2012). Aliran Permukaan pada Teknik Konservasi Tanah Guludan di Kelurahan Rurukan Kecamatan Tomohon Timur. Universitas Sam Ratulangi. Manado.

Nanik, Joko, S. (2017). Pemberian Mulsa dan Penguat Teras pada Tiga Jenis Tanaman Terhadap Limpasan Permukaan, Erosi, Pertumbuhan dan Hasil Tanaman pada Tanah Andisol. Agrosains.

Sa'adah, Lailis. (2015). Hubungan Tingkat Pendidikan Masyarakat dengan Pengetahuan Berkembangnya Lahan Terbangun di Kawasan Konservasi Tanah dan Air Kelurahan Sukorejo Kecamatan Gunung Jati. Universitas Negeri Semarang. Semarang

Subekti. (2004). Efektivitas Guludan dalam Mengendalikan Erosi Lahan. Universitas Diponegoro. Semarang 